\title{
Os limites do humano: \\ Restos humanos em um laboratório de genética forense
}

\author{
Claudia Fonseca* \\ Rodrigo Grazinoli Garrido**
}

\section{Resumo}

Nesse artigo, tomando como universo empírico um laboratório de genética forense, seguimos a trajetória dos pequenos pedaços de tecido tirados cirurgicamente de cadáveres humanos para estabelecer um perfil de DNA. Observamos que transformar tecidos já testados em material descartável, de forma a liberar o espaço físico para novas amostras, requer um investimento de energia institucional, envolvendo saúde pública, tribunais criminais e cemitérios públicos. Ao longo do percurso, o material corporal se mostra um ator dinâmica que, no âmbito das mediações técnicas da atividade pericial, realiza uma complexa coreografia, tocando em questões quanto aos limites do que é considerado "humano". Avançamos a hipótese de que, apesar das diferentes operações cunhadas para objetificar o material humano, transformando-o em resíduo descartável, os corpos acabam voltando para "assombrar" a produção científica de provas.

\section{Palavras-chave}

Antropologia da ciência. Materialidade relacional. Perícia. Restos humanos.

\section{Abstract}

In this paper, taking a forensic genetics laboratory as our empirical universe, we follow the trajectory of tissue fragments that have been surgically removed from human bodies to establish a DNA profile. We observe that the transformation of already-tested tissues into disposable materials, allowing for the liberation of physical lab space for new samples, requires the investment of tremendous institutional energy involving public health, criminal courts and public cemeteries. Throughout the the process, the body material proves to be

\footnotetext{
* Cláudia Fonseca é professora titular do Progama de Pós-graduação em Antropologia Social da Universidade Federal do Rio Grande do Sul (UFRGS). E-mail: claudialwfonseca@gmail.com.

** Rodrigo Garrido é Perito Criminal - Diretor do Instituto de Pesquisa e Perícias em Genética Forense (IPPGF) / Polícia Civil do Estado do Rio de Janeiro (PCERJ); Professor Adjunto da Faculdade Nacional de Direito (FND) da Universidade Federal do Rio de Janeiro (UFRJ) e do PPGD - Mestrado em Direito da Universidade Católica de Petrópolis (UCP).

E-mail: grazinoli.garrido@gmail.com .
} 
a dynamic actor, performing a complex choreography, as it moves through the technical mediations of evaluation, defining and redefining the limits of what is considered "human". In conclusion, we risk the hypothesis that, despite the different operations dictated to objectify the human remains, transforming them into disposable waste, the bodies come back to haunt the production of scientific evidences.

\section{Keywords}

Science Anthropology. Relational materiality. Forensics. Human remains.

\section{Introdução}

Nesses últimos tempos, sob a inspiração de teóricos como Bruno Latour (1994, 2005), antropólogos passaram a sublinhar a ideia de um ator-rede composto de "humanos" e "não humanos". Nesse tipo de abordagem, a grande inovação tem sido conferir "agency" não só aos humanos, mas também aos objetos ostensivamente inertes da vida material. De maneira semelhante, pesquisadores foram exortados a abdicar de visões dicotômicas, calcadas na divisão do mundo em esferas estanques - cultura $x$ natureza, moderna $x$ tradicional, nós x outros. Nesse tipo de "antropologia simétrica", a proposta fundamental é "abrir as caixas pretas" das abordagens clássicas, revendo noções preconcebidas que limitam o escopo e alcance de nossas análises. Eh bien, a colaboração entre os dois autores deste artigo - uma antropóloga e um especialista em genética forense - acabou por abrir a caixa preta dos próprios termos usados para descrever os elementos do ator-rede - "humanos" e "não humanos". A questão que se delineou e, de certa forma, a proposta deste dossiê é justamente: onde fica a linha divisora entre o que é o que não é humano?

Trazemos, nesse paper, a discussão sobre um objeto cuja liminaridade - humano/não humano - se constrói sobre bases particulares. Olhamos para os pequenos pedaços de osso ou tecido tirados cirurgicamente de corpos inegavelmente mortos para estabelecer, via análise laboratorial, um perfil de DNA capaz de identificar o defunto. Justamente, por não ter uma aparência humana e por não encerrar nenhum potencial de vida orgânica, essas matérias poderiam ser facilmente consideradas como objetos inertes provocando pouco interesse, senão total indiferença, quanto ao seu tratamento ou maneira de descarte. No entanto, são objetos que, por várias 
associações, ainda retêm algo do "humano", suscitando possibilidades que podem - dependendo da situação - exigir tratamento especial.

O problema de estudo do presente artigo surgiu a partir das dificuldades enfrentadas por um dos autores deste artigo (GARRIDO), diretor do Instituto de Pesquisa e Perícia em Genética Forense (IPPGF) do Rio de Janeiro, diante do que deveria ter sido um simples problema logístico para ele. O crescente reconhecimento desse laboratório forense tinha trazido um aumento de trabalho. Contudo, a infraestrutura do local tinha permanecido essencialmente a mesma desde sua abertura quase dez anos antes. Cada ano aumentava o número de testes realizados, significando o incremento progressivo de amostras biológicas chegando ao local. A questão era: como descartar os tecidos já testados de forma a liberar o espaço físico necessário para receber novas amostras destinadas a atender a novas demandas?

Ao aprofundar nossa reflexão sobre o funcionamento do IPPGF, descobrimos que o descarte deste material é, de fato, mais complicado do que aparenta ser. Transformar tecidos moles humanos e fragmentos de ossos em "lixo" descartável requer um enorme investimento de energia institucional, envolvendo negociações com autoridades de saúde pública, tribunais criminais e cemitérios públicos. Ao longo do percurso, o material corporal se mostra um ator dinâmico que, no âmbito das mediações técnicas da atividade pericial, realiza uma complexa coreografia, tocando em questões quanto aos limites do que é considerado "humano".

\section{A Materialidade Relacional dos Corpos Defuntos}

Barrando certas filosofias religiosas, é difícil conceber o "humano" sem a dimensão do corpo físico. No nosso argumento, pensamos esse corpo em termos da "materialidade relacional" de John Law e Annemarie Mol (1995), que apostam com a indissociabilidade do material e social ${ }^{1}$. Na abordagem "não humanista" desses autores, o ser humano aparece como o efeito relacional de uma rede ordenada. Sob essa perspectiva analítica, não seria possível falar de processos "desumanizantes", já que não existiria parâmetro a priori capaz de definir a essência humana. Entretanto, como

\footnotetext{
1 "[M]aterials are interactively constituted; outside their interactions they have no existence, no reality" (Law e Mol 1994, p.277).
} 
veremos mais adiante, o "humano" enquanto categoria moral não deixa de ser central para nossa análise. Nosso desafio consiste em rastrear os processos enredados das diversas produções dessa categoria.

Introduzir a questão de corpos defuntos envolve tanto a materialidade do corpo quanto a socialidade temporal envolvida na definição do "defunto". Autores como Lock (2002) e Allebrandt (2018) formulam seus estudos justamente para investigar zonas nebulosas nas quais o quê ou quem está vivo é debatível. Allebrandt, ao olhar para o destino de embriões que "sobram" nos tratamentos de reprodução assistida, trata de um material de certa forma pré-vivo, isto é, ainda não inteiramente humano. Destaca a importância da mediação tecnológica não só na produção e preservação desses embriões, mas na qualificação deles enquanto "excedentes", isto é, sem qualidade suficiente para alcançar o status de pessoa. Podemos dizer que se trata do revés da moeda das conturbadas tentativas de definir o material pós-vida envolvido no transplante de órgãos vitais (LOCK, 2002). O oximoro "cadáveres vivos" descreve bem a situação indefinida dos corpos sem atividades cerebrais (com "morte cerebral") mantidos mecanicamente em vida: enfim são pessoas ou são artefatos de suporte protético? Nos dois casos - o de embriões excedentes e o de cadáveres vivos - os objetos têm um status liminar. São úteis justamente por causa de seu vínculo - por tênue que seja - com uma pessoa viva; e, no entanto, não são pessoas plenas, pois não há salvaguardas contra sua exploração, e até mesmo sua destruição, em benefício de entidades "mais humanas".

Não devemos esquecer que, desde a época de nossos pais fundadores, etnógrafos registram determinadas práticas rituais elaboradas para circunscrever as fases do ciclo do corpo material - marcando os momentos quando este ainda pertence e quando sai da esfera humana, digna de consideração particular (MALINOWSKI, 1982). Legrand-Sebille (1998), por exemplo, conta como em muitos hospitais franceses, são os ritos funerários, colocando a criança em cena (vestida, fotografada, acompanhada de brinquedos, etc.), que assinalam a diferença entre o aborto de um feto e a morte de um bebê nascido prematuramente, entre a incineração do material junto com lixo hospitalar e o enterro.

A questão que se delineia em cada nova situação é: quanto tempo dura a consideração especial do corpo depois da morte da pessoa? Quando que um cadáver cultuado vira lixo descartável? A resposta a essa pergunta se remete à tremenda variedade de contextos históricos em que a morte assume diferentes contornos. Desde a Antiguidade, constata-se o culto aos 
restos mortais de líderes religiosos, militares e territoriais que, conforme os ventos, são mantidos como lugar de destaque entre os vivos (VERDERY, 1999). Por outro lado, historiadores nos lembram de que, até meados do século XIX, a morte de pessoas comuns não era objeto de grande cerimônia. Até os soldados mortos em batalha em defesa da nação raramente recebiam enterro individual (LAQUEUR, 2009). Quando seus nomes eram lembrados, era numa placa memorial antes do que num túmulo que abrigava o corpo material. A política de providenciar um enterro individualizado em cemitério público até para as pessoas mais humildes faz parte de um novo sentido de nação: o cadáver não devia mais ser tratado como lixo, mas como pessoa com significância política, observada, rastreada e ordenada (O'NEILL, 2012).

Por outro lado, a cova individualizada - que ganhou em importância junto com a crescente indignação diante de enterros em vala comum, em particular para indigentes - coloca distintos problemas logísticos nesse início do século XXI. O’Neill (2012), por exemplo, descreve a sobrelotação do cemitério urbano na cidade de Guatemala depois de décadas de violência - de guerra e de homicídio. Mas o entulhamento de defuntos nos cemitérios parece ser um problema comum à maior parte de metrópoles contemporâneas. De Londres e Hong Kong a Porto Alegre e Rio de Janeiro, tem surgido uma pletora de novas regulamentações sobre cemitérios em décadas recentes, não só para controlar a possível poluição ambiental (CONAMA, 2003), mas também para garantir a rotatividade de ocupantes dos túmulos. À medida que mingua o espaço para novas covas, os cemitérios implementam políticas mais agressivas de exumação e deslocamento dos restos mortais para ossuários e, finalmente, para incineração. Corpos que antigamente, pelo preço do funeral, tinham o direito implícito a um lugar de repouso para toda a eternidade, hoje têm direito a uma estadia cada vez mais curta. Não passam dez anos em alguns lugares, seis anos e mesmo três anos antes de os herdeiros responsáveis serem obrigados a efetivar novo pagamento de "aluguel". Como diz O'Neill, no atual regime neoliberal, a significância política do cadáver assim como o tratamento diferencial da pessoa post mortem são preocupações que parecem cessar junto com o fim dos pagamentos. Ousamos sugerir que, no processo, o poder aquisitivo acaba sendo um fator-chave para a definição dos limites temporais da condição humana. 


\section{Dando um Nome: as tecnologias de identificação}

No contexto do estado nacional contemporâneo, existem em geral normas para garantir um trato individualizado dos cadáveres humanos. Pode ser que o corpo do indigente siga uma trajetória relativamente modesta - enterrada em cova rasa, sem (ou com mínimos) ritos funerários, e com prazo curto para desfrutar do túmulo. Entretanto, no mundo ocidental hodierno, com a exceção de períodos de guerra e epidemia, a deferência pelo elemento humano exige uma individualização dos restos mortais. A essa individualização dos corpos, acrescenta-se a atribuição de um nome particular ao cadáver, um nome que evoca uma trajetória biográfica da pessoa que faleceu.

A atribuição de nomes nos traz diretamente para o laboratório de genética forense que pesquisamos. Embora também trabalhem com vestígios de cenas de crime e vítimas de estupro, a atividade que mais toma tempo e energia dos analistas nesse laboratório é a identificação de cadáveres não identificados ${ }^{2}$. Um dos primeiros casos do laboratório em 2005 tratou de um incêndio criminoso em que seis passageiros de um ônibus urbano haviam sido queimados vivos. Os técnicos do laboratório foram intimados a "dar um nome" aos corpos carbonizados que restaram. Outros casos podem incluir vítimas da guerra entre traficantes em que corpos foram "assados no micro-ondas" - colocados no meio de uma pilha de pneus e queimados até ficarem irreconhecíveis. Também podem chegar casos que envolvem vítimas de afogamentos que ficaram na água muito tempo, ou cujos restos mortais, por outras razões, estão muito deteriorados para fazer reconhecimento das marcas corporais distintivas ou mesmo de impressões digitais. Em certos casos, é possível identificar um cadáver pelos registros dentários ante mortem, mas para pessoas de baixa renda esse tipo de informação nem sempre existe. Assim, nesta e em outras circunstâncias, um exame de DNA é a última esperança para se saber exatamente quem morreu.

Antes de chegar ao IPPGF, o material corre um longo caminho. Na grande maioria de casos de morte, aqueles envolvendo pessoas que falecem

\footnotetext{
2 Em 2014, de acordo com registros internos, o laboratório processou um pouco mais de 350 amostras das quais mais de $70 \%$ referentes a cadáveres não identificados.
} 
por causas naturais e que são identificadas por meios tradicionais, as agências funerárias dão conta dos trâmites. O corpo da pessoa que morre em situação violenta ou por causas não esclarecidas segue para o IML. Após a necropsia se faz a necropapiloscopia. Atualmente, se não são identificados com esse método clássico, os "reclamados" seguem para a Antropologia Forense e Odontologia Legal, sempre na esperança de encontrar o nome individual $^{3}$. Os corpos identificados, mas não reclamados por parentes acabam enterrados como indigentes. Os que ainda não foram identificados serão submetidos a um exame de DNA pelo IPPGF.

Propomos que seria na etapa posterior, com a entrada no laboratório de genética forense, a ocorrência de certa reabilitação da socialidade biográfica desse indivíduo sob investigação. Já que só chegam ao laboratório vítimas de morte violenta, os corpos não identificados são todos merecedores de atenção cuidadosa. Como ouvimos de diversos membros do laboratório, a necessidade de botar um nome ao material recebido decorre do fato de que "sem vítima, não existe crime", i.é, sem corpo identificado e enredado numa história, é quase impossível inculpar um assassino.

Ironicamente, essa procura de biografia individual ocorre junto com certa sanitização do material físico. Diferentemente do IML, o laboratório de genética forense nunca recebe um cadáver inteiro, carregado de cheiros e imagens perturbadores. Ao invés, recebe fragmentos de ossos ou pedaços de outros tecidos humanos (músculo ou tegumento), medindo não mais que alguns centímetros. Cortados com precisão cirúrgica do cadáver por especialistas forenses no IML são enviados para o IPPGF em envelopes plásticos lacrados. O laboratório genético começa então, através de um cuidadoso procedimento protocolar, a extrair material celular e produzir um perfil de DNA único para o cadáver em questão.

O perfil, todavia, é um código, não um nome. Para estabelecer exatamente quem é o indivíduo, é necessário fazer uma comparação (match) entre a "amostra questionada" - isto é, o DNA extraído do fragmento ósseo - e uma "amostra de referência" i.é, o DNA de um parente próximo vivo. Junto com

\footnotetext{
${ }^{3}$ L. Ferreira (2009) sugere que, na época de sua pesquisa no IML-RJ, certa economia de esforços significava que bom número de corpos não identificados permanecesse com a designação "uma pessoa do sexo masculino (ou feminino)" ou simplesmente um número tal como "2007/01". Na opinião dessa autora, tratava-se de uma designação servindo menos para individualizar os corpos do que para contabilizá-los (2009, p.84).
} 
o envelope com a amostra de tecido mole ou fragmento de osso do IML, normalmente chega também o registro da ocorrência policial que revela nomes e números de telefone de possíveis parentes da vítima. Seguindo esta pista, o laboratório marca um dia e hora para que o parente provável visite o laboratório onde um técnico treinado, usando um cotonete, coletará uma amostra de células da mucosa oral.

Um caso típico seria o de Adroaldo (nome fictício), cujo "corpo carbonizado" foi encontrado na região da Praça Paris (Rio de Janeiro), em julho de 2009, e logo periciado no IML, com devido exame de necropsia, mas sem possibilidade de identificação precisa. Seis semanas mais tarde, a Delegacia encarregada de investigar esse homicídio estava encaminhando uma solicitação ao IPPGF para realizar um exame de DNA. Na documentação que acompanha o pedido, vemos como o corpo, originalmente designado por apenas um número (constatando do Guia de Remoção de Cadáver), adquire paulatinamente a possibilidade de nome e história. Duas chamadas de "Disque-Denúncia" atribuíram ao corpo carbonizado um nome que batia com um Registro de Desaparecimento, estabelecido um mês depois da queima do corpo por uma mulher preocupada com o sumiço de seu filho. Chamadas a depor, essa mãe e a companheira da "suposta vítima" não só reforçaram hipóteses quanto à identidade do cadáver como também forneceram pistas para identificar os assassinos. A partir de seus relatos, emergiu uma narrativa (apoiada também em variados registros policiais) em que a vítima teria sido eliminada a mando de um comparsa do tráfico de drogas, encarcerado naquele momento. No decorrer do processo, os assassinos que apareceram nos primeiros registros com nomes incompletos ou apelidos (ou simplesmente "Marcelo Quem Quem") também iam adquirindo uma identidade com nomes precisos. Para prender e levar os alegados malfeitores à justiça, faltava apenas a identificação "definitiva" da pessoa assassinada, impossibilitada até então pelo estado carbonizado do cadáver.

O que chega originalmente no IPPGF é um conjunto de cifras e números. Além da referência aos CIs abertos (um solicitando o envio de amostras de sangue colhido do coração da vítima; outro solicitando o exame comparativo de DNA entre o cadáver e a suposta mãe), há o número da Guia da Remoção de Cadáver Nºxx/2009, assim como o telefone de um policial da nona Delegacia de Polícia indicado para fazer contato com a mãe da vítima. Quase dois meses depois da morte de Adroaldo, sua "suposta mãe biológica” comparece no IPPGF onde, mediante apresentação de cópia 
reprográfica do documento de identidade (devidamente arquivada no Instituto), faz uma "doação espontânea" de sangue via punção venosa. A cadeia de custódia que garante a origem precisa de cada material testado depende de números rigorosamente registrados em cada etapa dessa pista de papéis. Só depois do "match", o cadáver de onde foi extraído o material inquirido vira oficialmente "Adroaldo", uma pessoa com nome, sobrenome, filiação e biografia confirmada. A transformação se consolida à medida que o material inverte a direção de sua trajetória original, remontando o caminho - do perfil genético à amostra de DNA, da amostra de DNA ao sangue, do sangue ao cadáver, do cadáver a uma pessoa singular.

Sugerimos que o próprio rigor dos procedimentos laboratoriais contribui para a humanização das amostras. Por razões tanto científicas quanto legais, é necessário registrar cada passo na trajetória do material: amostras devem ser protegidas contra contaminação por outro DNA, provas devem ser protegidas contra adulteração. Essa deferência ritual, expressa diante do objeto científico, mantém a singularidade de histórias individuais. A individualidade documental de cada amostra é o que garante que receberá um tratamento especial, distinto daquele destinado aos dejetos "profanos" do laboratório.

\section{A Crescente Demanda Esbarra Contra a Falta de Espaço}

Em meados de 2015, o Gabinete do Ministério Público Estadual circulou um ofício para os vários SMLs (Serviços de Medicina Legal) no estado do Rio de Janeiro sugerindo que, antes de enterrar qualquer corpo não identificado, deviam coletar uma amostra de tecido a ser enviado para o laboratório de genética forense na capital do estado onde um perfil de DNA seria definido e o material genético acautelado para futura investigação4.

O pedido do Ministério Público Estadual para realocar e preservar as amostras biológicas de cadáveres não identificados é fruto de mudanças

\footnotetext{
4 Esse pedido vem nos calcanhares do novo Regulamento Cemiterial e Funerário do Município de Rio Janeiro (Decreto 39094 de 12/08/2014) que, entre os outros novos detalhes, reza que: $\S 6^{\circ}$ No caso de indigente, findo o prazo de três anos, quando o respectivo corpo deve ser exumado, somados aos seis meses de respectiva guarda em ossuário para posterior incineração (parcial), deverá ser guardado, no mínimo, $2,5 \mathrm{~cm}^{2}$ (dois centímetros e meio quadrados) do maior osso do corpo humano, para fins de possível identificação civil através da técnica do DNA.
} 
tecnológicas introduzidas durante a última década nas atividades da polícia brasileira. Os interesses convergentes de pesquisadores acadêmicos, profissionais da polícia e empresas de biotecnologia- estabelecendo alianças nacionais e transnacionais - fizeram com que, logo depois da virada do século, houvesse uma demanda por um uso mais amplo e mais eficiente de testes de DNA para investigação criminal no país (FONSECA, 2013). Em 2002 o primeiro curso de Pós-Graduação em Ciência Genômica foi aberto em Brasília. Na mesma época, especialistas forenses do Brasil e do exterior começaram a organizar cursos de capacitação para introduzir peritos forenses às recentes possibilidades da tecnologia do DNA. Nos anos subsequentes, em diferentes partes do país, os congressos profissionais em genética forense e ciências criminais proliferaram e cresceram em tamanho, enfatizando sempre as vantagens das tecnologias de identificação por DNA. Com apoio de um lobby organizado, um projeto de lei foi introduzido no Congresso em 2011, prometendo grandes avanços na luta contra o crime. Aprovada em 2012 e regularizada em tempo recorde, a nova legislação formalizou um banco nacional de dados de perfis genéticos para condenados de crimes hediondos, dados que, através do software CODIS, poderiam ser facilmente vinculados a uma rede informática internacional que inclui o FBI e a Interpol (GARRIDO; RODRIGUES, 2015; RICHTER, 2016).

Enquanto a lei tramitava no Congresso, matérias sobre os potenciais benefícios dessa nova tecnologia começaram a aparecer na mídia nacional. Traziam histórias da Inglaterra ou dos Estados Unidos sobre assassinos seriais finalmente capturados, ou sobre prisioneiros injustamente condenados e finalmente inocentados - tudo graças ao banco de dados. Não é surpreendente que policiais e autoridades judiciais tenham começado a prestar mais atenção à preservação de materiais necessários para eventuais análises de DNA. Manchas de sêmen em casos de estupro, vestígios de cena de crime no caso de assassinato, assim como tecidos de corpos não identificados, todos eram agora potenciais candidatos ao banco de dados. Cada vez mais, essas amostras serviam como evidência no tribunal e poderiam complementar ou mesmo se sobrepor aos depoimentos de testemunhas oculares - se não de imediato, em alguma data futura. Perfis de DNA, argumentava-se, não se deterioram com o passar do tempo, nem são passíveis de ter seu código "objetivo" manchado pelas percepções emocionais das testemunhas. A mesma coisa seria válida para cadáveres não identificados. Os bancos de dados de DNA prometiam não só uma eventual solução para mistérios não resolvidos, mas também um instrumento para 
combater a impunidade de infratores da lei $\mathrm{i}^{5}$.

O Ministério Público do estado do Rio de Janeiro evidentemente considerou que a centralização dos materiais acautelados no IPPGF seria garantia da adequada preservação e uso regulamentar das evidências genéticas. $\mathrm{O}$ diretor do IPPGF concordou com pelo menos parte dessa demanda, afirmando por carta que "seria lógico" que o laboratório recebesse essas amostras, estabelecesse perfis de DNA e colocasse os perfis no banco de dados. O único problema era que, devido à falta de espaço, o laboratório forense da capital do estado simplesmente não tinha possibilidade de receber novas amostras biológicas. Assim, antes de atender ao pedido do MPE, alguns problemas logísticos haviam de ser solucionados.

Desde 2010, o laboratório vinha travando uma batalha para administrar a quantidade de materiais recebidos. É uma política antiga do laboratório lidar somente com "casos fechados", isto é, exames em que todas as amostras biológicas necessárias (tanto as questionadas como as de referência) estejam disponíveis. Em um memorando de 2012, aparentemente em resposta a uma demanda de autoridades superiores, o diretor do laboratório reiterou essa limitação, afirmando que o laboratório não poderia aceitar "casos abertos" exatamente porque não tinha a infraestrutura necessária para estocar o potencialmente grande número de amostras à espera de uma eventual utilidade futura. Em 2015, o diretor do laboratório deu uma reviravolta nessa política. Concordou, a princípio, em receber "amostras questionadas" de todos os corpos não identificados do estado, estando ou não acompanhados do nome de um possível parente, admitindo a possibilidade de uma enxurrada de amostras biológicas provenientes de "casos abertos". O diretor esclareceu, todavia, que seria impossível o laboratório implementar essa política antes de resolver uma questão central.

Como a planta física e o pessoal provavelmente se manterão inalterados no futuro próximo, a única forma de o laboratório abrir espaço para receber novos casos será descartar materiais residuais dos testes já concluídos. Esses resíduos incluem fragmentos de osso, pedaços de tecidos moles humanos e outros vestígios biológicos que já produziram um perfil de DNA claro - seja confirmando sua compatibilidade (match) com uma amostra de referência ou, depois de um segundo teste com um resultado idêntico, confirmando

\footnotetext{
${ }^{5}$ Veja Richter (2016) sobre essas promessas.
} 
uma exclusão. Quando os resultados de um teste, mesmo após um segundo teste, são inconclusivos - pondera o diretor- faz sentido guardar a amostra biológica original. Quem sabe se, no futuro, novas tecnologias mais refinadas não serão capazes de estabelecer um perfil? Na maioria esmagadora dos casos, porém, a primeira bateria de testes produz um perfil de DNA.

As extrações de DNA, cuidadosamente preservadas em microtubos de polipropileno, ocupam espaço mínimo. Por outro lado, os "centímetros" ocupados pelas amostras biológicas originais - fragmentos de ossos ou tecidos moles - tomam bem mais espaço. São essas amostras já testadas e tendo dado resultados claros que o laboratório aspira descartar para poder continuar funcionando. Há sérias dúvidas quanto à futura utilidade desse material. Nos seus dez anos de funcionamento, o laboratório recebeu apenas um pedido para reanalisar uma amostra biológica - procedimento que resultou na confirmação do perfil genético produzido pelo teste anterior. Além do mais, devido à falta de câmera fria e outras tecnologias adequadas de armazenagem, muitas amostras biológicas se deterioram ao longo do tempo a ponto de serem inúteis para um exame de DNA.

\section{Lixo, Evidência ou Restos Mortais?}

Até 2011, o laboratório seguiu um procedimento administrativo relativamente simples para descartar materiais biológicos que não teriam mais uso. Uma ou duas vezes ao ano, uma comissão de profissionais designados para supervisionar esse procedimento estabelecia uma lista de 100 a 150 amostras já examinadas para serem "inumadas", informando de cada uma a origem, a vara criminal ou a delegacia que solicitou o teste, assim como o número do inquérito. Submetida às autoridades administrativas apropriadas, essa solicitação era rotineiramente aprovada. Em 2011, logo quando o novo projeto de lei congressional estava sendo lançado e a administração da Polícia Técnico-Científica passava a incluir especialistas qualificados em genética forense, as coisas começaram a ficar mais complicadas.

No início de 2011, a comissão do laboratório enviou ao Diretor da Polícia Técnico-Científica um ofício solicitando permissão para descartar materiais detalhados em uma lista anexa:

“[...] Estas amostras foram examinadas, tendo seus resultados descritos de forma conclusiva em laudos do IPPGF. Outrossim, 
informo que os materiais biológicos já não se prestavam para análises em virtude de estarem bastante deteriorados e os dados genéticos, bem como uma amostra do DNA de tais materiais permanecerão acautelados no IPPGF. Por fim, esclareço que tal ação se faz necessária para desafogar nossas geladeiras, freezers e câmara fria".

O pedido de rotina voltou duas semanas depois com uma nota escrita à mão pela autoridade superior mostrando evidente preocupação com a possível destruição de evidências ${ }^{6}$. Perguntava se os materiais "ainda que deteriorados" não permitiam a extração de material genético. Também queria saber quais previsões legais existiam sobre a "destruição de amostras" e qual era a rotina para tal procedimento em outros estados da federação. A documentação mostra como, ao longo dos próximos meses, numa saga que envolveu a assessoria jurídica da polícia, seguiu-se a busca aparentemente infrutífera por uma lei relevante. Escrita à mão em baixo de um ofício, se encontra a nota frustrada de um consultor: "[sobre o que fazer com as sobras de amostras] informo que não foi encontrada legislação específica sobre o assunto; apenas localizei a Lei Federal [...] que trata do descarte de organismos geneticamente modificados - OGM". Aparece a menção de uma lei de 1992 sobre o uso de cadáveres não identificados para ensino e investigação científica, mas com a ressalva de que não menciona nada sobre o que deveria ser feito com o corpo (ou partes dele), uma vez que não seja mais útil. Depois de consultar laboratórios forenses em outros estados, o diretor do laboratório pessoalmente afirma que não existe lei sobre esta questão: "Alguns estados estão acautelando os materiais até os limites de seus estoques em geladeiras e freezers, podendo gerar em breve um problema de saúde pública".

Finalmente, no começo de abril (2011), a consultora encarregada de investigar a situação decidiu que, sendo evidência dos tribunais, as amostras biológicas não pertenciam à polícia e sim aos juízes e promotores de cada julgamento. Por conseguinte, a Direção da Polícia TécnicoCientífica determinou que, antes de descartar qualquer amostra biológica, o laboratório deveria ter permissão escrita das duas principais autoridades

\footnotetext{
${ }^{6}$ A referência implícita dessa preocupação é o bem conhecido artigo 170 do Código de Processo Penal: “Nas perícias de laboratório, os peritos guardarão material suficiente para a eventualidade de nova perícia" (Ênfase nossa).
} 
legais (juiz e promotor) envolvidas em cada um dos casos. Deve-se notar que, se contarmos as varas e promotorias criminais em todo o estado do Rio de Janeiro (qualquer uma das quais pode ter solicitado a opinião dos especialistas do IPPGF), esse processo poderia envolver pelo menos 100 juízes diferentes e um número igual de promotores.

Uma leitura nos arquivos do IPPGF de um dos poucos casos que receberam a permissão de um juiz demonstra quanta energia burocrática pode ser investida nessa empreitada. Primeiro, a vara criminal apropriada tem que ser identificada e contatada. O juiz responsável emite então um pedido oficial para que tudo que se refira ao caso seja resgatado dos arquivos. Consultados os processos desarquivados, toma-se nota dos códigos e números que levam aos relatórios relevantes dos laboratórios do IML e do IPPGF. Inúmeras cartas são trocadas entre os promotores e o juiz. Não surpreende que a maioria dos pedidos de permissão fique sem resposta. Diante desse impasse, a comissão do IPPGF encarregada de descartar velhas amostras fez o que foi necessário a fim de garantir o exercício apropriado das atividades do laboratório: foi em frente com o descarte dos materiais acumulados.

Todavia, em 2015, exatamente no momento em que crescia a demanda pelos serviços do laboratório e a necessidade de garantir a rotatividade (e o consequente descarte) de materiais, surgiu um novo obstáculo. Uma vez tomada a decisão de mover pedaços de tecidos moles e ossos para fora do laboratório, a questão é: "para onde?" É notável que ninguém do laboratório jamais tenha considerado descartar os pequenos fragmentos de ossos com o lixo do hospital. Parece ser de concordância geral que, por tratar-se de restos humanos, o material merece tratamento especial.

A maioria dos fragmentos de ossos enviados para exame vem de um dos muitos SML's do estado. Esses necrotérios policiais presentes na maioria das cidades brasileiras estão habituados a lidar com cadáveres, ossadas e despojos humanos que, depois de examinados, são despachados. Assim, via de regra, o laboratório de genética forense seguia o caminho lógico de enviar os restos do seu material de volta ao IML da capital onde seriam inumados junto com os muitos cadáveres não reclamados. No início de 2015, todavia, surgiram obstáculos nesse caminho. Como de costume, depois de avisar por telefone o diretor do IML, a direção do IPPGF tinha feito uma remessa de fragmentos para serem enterrados. Contudo, essa vez, o material foi barrado na porta de entrada do IML com uma explicação do técnico de necropsia: "Hoje em dia, é um problema se livrar dos nossos 
próprios materiais! Como que nós vamos tomar conta dos descartes de outro laboratório?".

Não estava bem claro o que havia acontecido para criar essa dificuldade, mas o diretor do IPPGF levantou uma hipótese com base no que ele havia lido nos jornais. Até recentemente, a Santa Casa de Misericórdia - uma instituição filantrópica privada - continuava a coordenar a administração de quase todos os cemitérios da cidade, mesmo depois de encerrado o seu contrato oficial em 2009. Todavia, em 2013, a polícia descobriu um esquema de venda ilegal de espaço para túmulos a preços exorbitantes, e a subsequente investigação resultou na contratação pelo município de entidades administrativas novas ${ }^{7}$. O diretor do IPPGF nunca tinha tido total clareza de como o IML lidava com a inumação dos fragmentos humanos que eles recebiam de volta. Certamente, o material era enterrado em um cemitério, mas ele suspeitava que a maioria dos arranjos entre o IML e o cemitério era feito numa base informal. Talvez o cemitério aceitasse o material como um serviço público, sem cobrar, incorporando os fragmentos, junto com restos de túmulos antigos, no ossuário coletivo. Com a mudança de administração, seguida de controles mais rigorosos, é possível que as negociações informais para a inumação de restos humanos vindos de laboratórios forenses públicos tenham se tornado mais complicadas ${ }^{8}$.

Seja qual fosse o motivo da mudança de política no IML, o descarte dos tecidos residuais dos testes genéticos tinha se tornado ainda mais problemático. Para sublinhar a seriedade do seu dilema, o diretor do IPPGF lembra (em entrevista realizada durante nossa pesquisa) a bem conhecida técnica de descarte de prisioneiros políticos durante a ditadura brasileira: "O que eu faço? Jogo o material na Baía de Guanabara como os militares costumavam fazer com seus cadáveres?". Aparentemente, a memória de corpos "desovados" pelas forças de segurança durante a ditadura militar permanece no imaginário público, exigindo uma transparência ordenada no descarte de tecidos que exclui a possibilidade de atividades obscuras

\footnotetext{
7 Veja, por exemplo: http://g1.globo.com/rio-de-janeiro/noticia/2013/07/policia-faz-operacao-emcemiterios-no-rio-apos-denuncia-de-fraude.html, e http://g1.globo.com/rio-de-janeiro/noticia/2014/08/ rio-comeca-nova-gestao-em-cemiterios-apos-saida-da-santa-casa.html.

8 Rumores chegaram ao laboratório de que o Ministério Público Estadual havia mediado um acordo entre a Prefeitura e os cemitérios públicos para que a separação e a individualidade dos fragmentos de ossos não identificados fossem preservadas.
} 
ou acobertadas. De forma análoga, receios quanto à violência exercida por autoridades atuais aparecem, por exemplo, num pedido pelo Ministério Público de São Paulo, depois de uma onda de violência policial, para não enterrar os corpos não identificados antes de realizar todas as perícias adequadas.

Procurando novas alternativas, ele fez contato com o cemitério de uma cidade interiorana do estado que aceitaria inumar os fragmentos. Mas os obstáculos burocráticos não chegavam ao fim. O procedimento protocolar exigia um transporte controlado do material, em veículo oficial. Naquele momento, os dois carros do laboratório (um deles, com mais de dez anos) estavam inoperantes por falta de manutenção (pneus carecas, baterias fracas, freios desregulados e falhas elétricas $)^{9}$. E, assim, continuava o "engarrafamento", que impedia o pleno aproveitamento dos recursos do laboratório.

\section{Ossos que Falam}

O que fazer com o material que resta depois do fim do teste de DNA? É lixo a ser descartado? É prova a ser preservada? Ou são restos mortais a serem cultuados? As peripécias da equipe do IPPGF, nas suas tentativas de se livrar desses "resíduos", revelam o amplo leque de atores envolvidos na resposta a essas questões. Trata-se de uma clara ilustração da "materialidade relacional" evocada no início deste artigo. Tudo, desde cemitérios entulhados e carros quebrados até memórias da ditadura e corrupção política e policial, pode influenciar na definição de quem, exatamente, deve tomar a responsabilidade de decidir se esses objetos serão significados como lixo, provas judiciais ou humanas.

Central a essa equação, o agency da própria tecnologia de DNA não deve ser subestimado. Ao estender os tempos-limite da prova material, e, por extensão, de possíveis apelações e novos julgamentos, essa inovação tecnológica decretou a obsolescência de muitos dos precedentes jurídicos convencionais. No caso descrito neste artigo, vemos as tentativas em vão do

\footnotetext{
${ }^{9}$ Trata-se de uma situação que, conforme relatório recente, não é incomum em outros laboratórios forenses espalhados pelo país (SENASP, 2012).
} 
diretor da polícia Técnico-Científica para encontrar uma lei ou, pelo menos, algum precedente legal para dar aval a suas decisões sobre o descarte de amostras biológicas. Na ausência de referências estabelecidas, o que ocorre é uma espécie de "jogo de empurra". A decisão final é deixada para juízes e promotores em jurisdições descentralizadas - pessoas que, podemos presumir (pela falta de suas respostas às petições), têm pouco interesse ou competência técnica para avaliar a questão. $\mathrm{O}$ resultado é uma espécie de impasse no qual, por falta de regulamentação clara, os operadores mais próximos do problema imediato resolvem a questão de acordo com suas próprias avaliações pessoais e profissionais.

Previsivelmente, existem divergências de opinião. Do ponto de vista dos especialistas do IPPGF, é difícil entender por que as autoridades judiciárias e policiais têm tanto apego às amostras biológicas. Devemos lembrar que o laboratório só pede para inumar aqueles materiais que já foram testados e deram claros resultados quanto ao perfil de DNA. Por que a amostra biológica teria mais solidez enquanto prova do que o microtubo contendo o DNA extraído da amostra? É a pergunta colocada pelos especialistas do laboratório. Tudo bem, pode haver dúvidas quanto à "autenticidade" do conteúdo do microtubo, mas quem garante a autenticidade da amostra biológica? Como saber se foi extirpada do corpo registrado no papel? E, mesmo exumando o cadáver, como ter certeza de que se trata do cadáver específico que aparece na narrativa contada pelos laudos policiais? Por que, nessa cadeia de incertezas, a amostra biológica adquire um peso de tamanha importância?

O apego às amostras biológicas é ainda mais curioso diante do entusiasmo global pelas tecnologias genéticas, badaladas em muitas instâncias como "máquina de verdade", capaz de produzir respostas definitivas a situações mal-esclarecidas e moralmente ambíguas (ANSTETT; DREYFUS, 2015). Smith (2013) chama atenção para América Latina em particular, onde investimentos na identificação de pessoas mortas ou sequestradas pelas ditaduras militares têm provocado uma associação quase automática entre justiça, DNA e os direitos humanos. A autora ressalta como, especialmente em Guatemala, os laboratórios genéticos continuam a ser destacados como "ícones" de justiça e acerto de contas malgrado parcos resultados. Aqui, apoiados em rituais laboratoriais da ciência protocolar, as técnicas genéticas adquirem determinada aura afetiva, quase sagrada: 
"Muitas vezes, o êxito [dessas técnicas] dependia, na prática, menos na capacidade dos cientistas de inovar ou mesmo de identificar alguém, do que na rotina cotidiana, repetitiva para processar amostras com um determinado tipo de cuidado cuidado com os mortos, cuidado com o passado, cuidado com o status de "certificação" [científica do laboratório], e cuidado com a democracia". (SMITH, 2013, p.4).

Distanciando-se dos analistas mais ufanistas das tecnologias de DNA aqueles que parecem pressupor sua eficácia quase automática na promoção de justiça -, Smith (2013) procura entender os efeitos mais difusos e amplos. Tratando a genética como "fé", os laboratórios genéticos se revelam como sítios de cuidado e purificação intensivos, que ajudam a recompor uma memória da nação.

Sugerimos que, quando são materializados em um osso ou fragmento de tecido humano, a fé e o afeto são de ordem algo diferente. Há considerável distância entre o efeito de um artefato ultramoderno - a extração do DNA acondicionada em microtubos - e o efeito de pedaços de um cadáver humano. Estes podem ser vistos, cheirados e apalpados. São de certa forma mais "poluídos", mas é precisamente essa poluição que os torna símbolos potentes, capazes de mobilizar ideologias políticas, causas humanitárias e identidades étnicas. São esses materiais que têm fomentado embates na época pós-colonialista entre museólogos e povos originários que reclamam a devolução dos restos corporais de seus antepassados. Vide as controvérsias sobre o cérebro de Ishi, o último dos índios Yoshi, armazenado em um depósito do Smithsonian Institute (STARN, 2004); sobre a custódia do conteúdo de uma sepultura pré-histórica encontrada numa reserva indígena no estado americano de Washington (TALLBEAR, 2013); ou sobre os biobancos formados com o sangue dos índios Yanomami, estocado por geneticistas e antropólogos físicos em universidades da América do Sul e do Norte (DINIZ, 2007). Em cada uma dessas situações, é possível rastrear as relações sociais e políticas de curta e longa duração, que produziram a importância dessas relíquias de identidade coletiva. Vassallo (2017), no seu estudo sobre um cemitério de escravos na região portuária de Rio de Janeiro, sublinha o caráter dinâmico desse tipo de "materialidade relacional" ao descrever como, ao longo das últimas décadas, escombros de uma obra de construção foram transformados de entulho em objeto de investigação científica e, por fim, em ossos sagrados, objeto de culto religioso. 
Há de se perguntar se um artefato asséptico de laboratório científico, tal como um microtubo contendo extrato de DNA, teria o mesmo potencial mobilizador. Na situação descrita neste artigo, estamos longe dos movimentos sociais à procura de símbolos de identidade coletiva. Estamos lidando com um circuito de especialistas (em direito e em perícia forense) dentro de estruturas administrativas de governo. Cabe, nesse sentido, refletir sobre o significado do corpo, material humano nesses ambientes profissionais.

As controvérsias clássicas envolvendo o exame de cadáveres humanos talvez ajudem a entender a lógica dos especialistas médicos e jurídicos. Analistas da história ocidental falam repetidamente da importância da preservação, depois da morte, da integridade do corpo (SAPPOL, 2001). O imperativo dessa integridade dificultava a pesquisa via dissecção de cadáveres ao longo da época moderna. Antes de meados do século XIX, quando foram editadas as primeiras leis regulando o uso de cadáveres para fins didáticos, os estudantes de medicina eram obrigados a se apoiar em atividades transgressivas - $\mathrm{o}$ arrombamento de túmulos, a profanação de cemitérios - para realizar a contento suas aulas de anatomia. Enquanto os médicos em formação adquiriam um status privilegiado através do rito de passagem da dissecção do corpo humano, os populares que se identificavam com os cadáveres dissecados (escolhidos entre indigentes, criminosos, loucos, escravos e outras categorias desprezadas) organizavam protestos populares contra essa prática (SAPPOL, 2001). Ainda hoje, escavações arqueológicas em torno das antigas escolas de medicina confirmam os receios públicos de que mesmo os corpos legalmente adquiridos não eram tratados com a dignidade de defuntos de categorias mais respeitáveis. Como comenta uma analista contemporânea dos escombros da antiga escola de medicina em Harvard, não era só o fato de cadáveres serem usados como recursos didáticos e científicos que escandalizava o público. Depois do uso do material, havia uma profanidade na maneira de descarte que negava a própria humanidade desses corpos (HODGE, 2013).

Ainda no século XIX, enquanto a dissecção de cadáveres tornava-se padrão não só aceitável, mas necessária no campo da medicina, a autópsia de pessoas que tinham sofrido uma morte violenta passava a se impor na área de Direito. A ideia de que o corpo do defunto assassinado encerrava um poder especial para identificar o assassino não era nova. Até o início da era moderna, existem relatos de cadáveres voltando à vida ou dando outros sinais de acusação quando na presença do malfeitor (CROSSLAND, 2009). 
Mas a emergência, no século XIX de um novo estilo de raciocínio científicoo paradigma evidencial, que através do exame de detalhes diminutos revelava verdades de outra forma invisíveis ao observador (GINZBURG, 1989) - transformou o tipo de "agency" atribuído ao cadáver.

A nova abordagem científica que se consolidava então exigia a "objetividade" dos cientistas. "Provas" deviam ser constatadas mecanicamente por métodos que afirmavam a realidade dos objetos, independentemente do contexto, independentemente das relações ou interesses que os circundavam. A dissecção ou a autópsia transformava o cadáver em objeto de expertise, capaz de conferir um status especial à classe de profissionais que tinham acesso a ele. Para esses expertos, era um ponto de honra adquirir um olhar que enxergava no defunto não uma pessoa e, sim, uma mina de partes anatômicas capazes de gerar novos conhecimentos científicos (HODGE, 2013). O "agency" dos ossos e tecidos se afastou de antigas visões que privilegiavam um efeito-fantasma, devido às influências residuais da personalidade individual. O fragmento corporal virou um "objeto" autônomo e inflexível, capaz de opor "objeções" às mentiras e fornecer informações que nem mesmo o próprio defunto, quando ainda em vida, não seria capaz de formular.

“O tratamento dos corpos como prova simultaneamente nega e reconhece os aspectos misteriosos dos mortos, reprimindo quaisquer noções de que os mortos teriam uma agência incontrolável ou assombradora, e, ao mesmo tempo, dotando os mortos de uma agência cuidadosamente canalizada e constrangida pela sua aparência como objeto de análise" (CROSSLAND, 2009, p.75).

No entanto - e é nisso que reside a possível explicação da insistência jurídica em guardar as amostras biológicas no IPPGF- antigos paradigmas mais "mágicos" ainda fazem parte do quadro imaginário atual. A arqueóloga forense Zoe Crossland (2009) recorre à análise semiótica de Peirce para apoiar essa hipótese. No esquema peirceano, existem diversas maneiras para evocar um objeto. Dessas, o signo indexical- que, tal como a fumaça para o fogo, pressupõe uma contiguidade física com o objeto representado seria particularmente evocativo, pois reivindica uma realidade arraigada no mundo material. Nesse sentido, um osso (ou outro fragmento corporal) traz a concretude de um passado embalsamado, com o poder de convencimento semelhante ao dos antigos cadáveres que "falavam". Um microtubo ou 
mesmo um código numérico de DNA são símbolos do corpo ausente, cuja verdade deve ser construída através da "indexicalidade secundária" dos especialistas (eles cotizaram o objeto material e traduziram o resultado em nova forma). Tal como os microtubos e os perfis numéricos, o "agency" do fragmento corporal também depende de uma rede de relações complexas que inclui arqueólogos, peritos, policiais, parentes e as diversas tecnologias com as quais trabalham. Porém, como na magia simpática, o fragmento traz a memória de uma convivência material com a realidade sendo investigada. $\mathrm{O}$ apego persistente a essa materialidade humana da prova sugere que, apesar de a ciência contemporânea ter se pautado pela superação de crenças mágicas, estas convivem de forma tranquila no contexto moderno de alta tecnologia. De certa forma, os corpos acabam voltando para "assombrar" a produção científica de evidências.

\section{Referências}

ANSTETT, Elizabeth; DREYFUS, Jean-Marc (Orgs.).

(2015). Human remains and identification. Mass violence, genocide, and the 'forensic turn'. Manchester, Manchester University Press.

\section{ALLEBRANDT, Débora.}

(2018). Negociando o destino dos embriões humanos produzidos na reprodução assistida: Criopreservação, descarte, doação e seus agenciamentos em uma clínica de Porto Alegre. Interseções, v.20, n.1.

CONAMA (CONSELHO NACIONAL DO MEIO AMBIENTE)

(2003). Resolução Conama no 335, de 3 de abril de 2003; Dispõe sobre o licenciamento ambiental de cemitérios. Disponivel em: http://www.mma.gov.br/port/conama/ legiabre.cfm? codlegi=359.

CROSSLAND, Zoê.

(2009). Of Clues and Signs: The Dead Body and Its Evidential Traces. American Anthropologist, v. 111, n.1, p. 69-80.

DINIZ, Debora.

(2007). Avaliação ética em pesquisa social: 0 caso do sangue Yanomami. Revista Bioética, v. 15, n.2, p. 284-97.
FERREIRA, Leticia Carvalho de $M$.

(2009). Dos autos da cova rasa: a identificação de corpos não-identificados no Instituto Médico-Legal do Rio de Janeiro, 1942-1960. Rio de Janeiro, E-papers / LACED / Museu Nacional.

FONSECA, Claudia; GARRID0, Rodrigo.

(2016). Lixo, restos humanos, e genética forense: 0 caso de um laboratório de polícia do Rio de Janeiro. In: Carmen Silvia Rial (0rg.); 0 poder do lixo: abordagens antropológicas dos resíduos sólidos. Rio de Janeiro, ABA.

GINZBURG, Carlos.

(1989). Sinais: Raizes de um paradigma indiciário. In: Mitos, emblemas e Sinais: Morfologia e história. São Paulo, Companhia das Letras,

HODGE, Christina.

(2013). Non-bodies of knowledge: Anatomized remains from the Holden Chapel collection, Harvard University. Journal of Social Archaeology, February. v. 13 n.1, p. 122-149.

LAQUEUR, Thomas.

(2009). Mourning, pity, and the work of narrative in the making of "humanity". In: Richard Wilson; Richard Brown (Orgs.); 
Humanitarianism and suffering: the mobilization of empathy. Cambridge, Cambridge University Press.

\section{LATOUR, Bruno.}

(1994). Jamais fomos modernos: ensaio de antropologia simétrica. Rio de Janeiro, Editora 34.

LATOUR, Bruno.

(2005). Reassembling the social: an introduction to actor-network theory. 0xford, 0xford University Press.

LAW, John; MOL, Annemarie.

(1995). Notes on Materiality and Sociality. The Sociological Review, v.43, n.2, p. 274-294.

LEGRAND-SEBILLE, Catherine et al. (Orgs.). (1998). Le fœtus, le nourrisson, et la mort. Paris, Harmattan.

LOCK, Margaret.

(2002). Twice dead: Organ transplants and the reinvention of death. Los Angeles, University of California Press.

MALINOWSKI, Bronislaw

(1982). A vida sexual dos selvagens. Rio de Janeiro, Francisco Alves.

0’NEILL, Kevin Lewis.

(2012). There is no more room: Cemeteries, personhood, and bare death. Ethnography, v.13, n.4, p. 510-530.

RICHTER, Vitor.

(2016). Identificação genética e crime: a introdução dos bancos de DNA no Brasil. Tese de doutorado apresentada ao Programa de Pós-Graduação em Antropologia Social da Universidade do Rio Grande do Sul (UFRGS).

SANTOS, Flavia Medeiros.

(2014). 0 'Monstro' e o 'Homem': Aspectos da construção institucional de mortos no Instituto Médico Legal do Rio de Janeiro. DILEMAS: Revista de Estudos de Conflito e Controle Social, v.7, n.2, p. 347-365.
SAPPOL, Michael.

(2001). A Traffic of Dead Bodies: Anatomy and embodied social identity in nineteenthcentury America. Princeton, Princeton University Press.

SMITH, Lindsay.

(2013). Genetics is a Study in Faith: Forensic DNA, Kinship Analysis, and the Ethics of Care in Postconflict Latin America. Disponivel em: http://sfonline.barnard. edu/life-un-ltd-feminism-bioscience-race/ genetics-is-a-study-in-faith-forensic-dnakinship-analysis-and-the-ethics-of-care-inpost-conflict-latin-america/ . Acesso em 10 de agosto de 2017.

STARN, Orin.

(2004). Ishi's Brain: In search of America's last "wild" indian. New York, W. W. Norton \& Company.

TALLBEAR, Kim.

(2013). Native American DNA: tribal belonging and the false promise of genetic science. Minneapolis: University of Minneapolis Press.

VASSALLO, Simone Pondé.

(2016). De "objetos da ciência" a "restos mortais ancestrais": patrimônio, política e religião no Cemitério dos Pretos Novos, no Rio de Janeiro. In: Edlaine Gomes; Paola Lins Oliveira (Orgs.); Patrimônio religioso no Rio de Janeiro. Rio de Janeiro, Ed. Mar de idéias.

VERDERY, Katherine.

(1999). The Political Lives of Dead Bodies: reburial and postsocialist change. New York, Columbia University Press.

\section{Recebido em}

outubro de 2017

\section{Aprovado em}

fevereiro de 2018 